\title{
Turkey's changing security discourses: The challenge of globalisation
}

\author{
PINAR BILGIN
}

Department of International Relations, Bilkent University, Ankara, Turkey

\begin{abstract}
The aim of this article is to analyse the ways in which Turkey's security discourses have been shaped by, and have sought to shape, the transformation Turkey has gone through in recent years. It was as a part of the process of joining the European Union (EU) that the challenge of globalised security was strongly felt in Turkey. Since the Helsinki decision of 1999 to include Turkey in the list of official candidates, there emerged an elite-level debate regarding the security implications of the reforms demanded by the EU. Whereas the 'Eurosceptics' have underlined the need for a broad security agenda by making references to 'globalised security' while seeking to shape practices in defense of 'national security', the 'pro-EU' actors have opened up Turkey's definition of 'national security' for debate thereby sowing the seeds of an alternative security discourse. The article falls into three sections. The first section discusses the relationship between security and globalisation and gives examples from the Turkish case. The second section looks at the 'traditional' discourse on security that has prevailed during the Republican era. The third section seeks to identify the changes in the 1990s in Turkey's security discourses by focusing on the debates on the EU. The article concludes by considering the likelihood of further changes in Turkey's security discourses.
\end{abstract}

How has Turkey responded to the challenge of globalised security? Some point to the broadening of Turkey's national security agenda to include internal as well as external security issues, and the convergence of foreign and security policies during the 1990s, and maintain that the civilian-military bureaucratic elite's response has been that of seeking to resist the pressures for transformation (Cizre 1997; Özcan 1998). In doing this, the military has increasingly chosen to represent its role in shaping political processes as responses to a strategic environment conceived in terms of globalisation (Yirmibeşoğlu 2003; Recep 2002). It has also changed its methods during the 1990s and taken advantage of the opportunities for political mobilisation made possible by globalisation to make inroads into Turkish society (Cizre 2000: 4; Jenkins 2001: 40 ) and create an environment that is receptive to its definition of 'national security'. The Ministry of Foreign Affairs, on the other hand, is considered to have failed to initiate a process of bureaucratic innovation in response to the globalisation of world politics (Çandar 2001: 60) in that other actors (some 
'traditional' as with the military, and some 'new' as with sub-state and transnational non-governmental actors) have taken over its central role in the shaping of policies. Others emphasise the effects of economic liberalisation on the Turkish state and society and argue that the rising importance of economic considerations in external affairs has increased the roles played by 'new' actors (including the business elite and civil societal organisations) (Öniş \& Türem 2001). This is considered to have helped to introduce 'a significant element of transnationalism' into the outlook of the civilian-military bureaucratic elite thereby diminishing (albeit gradually) the role played by the military in shaping political processes in Turkey (Karaosmanoğlu 2000). Still others highlight the impact the European Union (EU) has made on the shaping of political processes in Turkey and place their hopes on the EU accession process which, they expect, would 'create a wedge between the state and some of its allies in society, especially some business organizations, which will push for reform at a faster pace than what the civilian-military bureaucratic elite is prepared to accept' (Barkey 2000: 105; also see Öniş 2003).

Notwithstanding the differences, these readings of developments in the 1990s point to changes in Turkey's security discourses in response to the challenge of globalised security in that while the civilian-military bureaucratic elite have had to shift their discourses (or face marginalisation), 'new' actors have become increasingly vocal. Although Turkey has had to deal with 'strategic globality' for a long time, the process of joining the EU posed challenges that involved the adoption of international societal norms, which are perceived by some to threaten Turkey's 'national security'. Such norms weaken the grip of the state over political processes and introduce 'new' actors who challenge established approaches to issues (such as cultural pluralism, linguistic rights or gender relations) that are considered 'sensitive' by some.

Explaining the Turkish state's responses to the forces of globalisation, Kasaba and Bozdoğan (2000: 19) wrote:

So far, the signs are overwhelmingly positive in that the government has shown a strong willingness to further the social and economic liberalisation in the country. ... There is also a reinvigorated sense of openness in the country, where each day the media probes into what is euphemistically referred to as the 'deep state'.

However, notwithstanding the 'ideological, cultural, political and economic debates that are flourishing in all sections of society [to] directly question the centrality of state institutions and practices' (Kasaba \& Bozdogan 2000: 19), issues to do with security were left relatively untouched. The aim of this article is to analyse the ways in which Turkey's security discourses have 
been shaped by, and have sought to shape, the transformation Turkey has gone through in recent years as part of the process of preparing for European integration. Following Milliken (1999b: 12), discourse is understood here as 'an ordering of terms, meanings and practices that forms the background presuppositions and taken-for-granted understandings that enable people's actions and interpretations' (also see Milliken 1999a). The article will analyse language practices of various (state and non-state) actors in order to show how they seek to render proper certain policies while marginalising alternative courses of action. It will be argued that since the Helsinki decision of 1999 to include Turkey in the list of official candidates for accession, there has emerged a debate regarding the security implications of the reforms demanded by the EU. Although the debate has remained at the elite level, it has nevertheless helped to crystallise the differences between and within various actors (namely, 'Eurosceptic' and 'pro-EU' actors) with regard to the issue of EU membership.

Interestingly, both sides to this debate have chosen to present their positions as responses to an environment conceived in terms of globalisation. The discourse of the Eurosceptics has underlined the need for a broad security agenda by making references to globalised security while seeking to shape practices in defence of national security - that is, within an inter-state framework, albeit with a dash of multilateralism (Illhan 2000; Manisalı 2001, 2002). On the other hand, pro-EU actors, who have long emphasised the economic and political dimensions of globalisation often to the neglect of security issues (see, e.g., Ugur 2003), began to develop an alternative discourse on security when making the case for EU membership (Türkmen 2001; Ergüvenç 1999, 2000a, 2000b) and sought to question the relevance of the existing definition of 'national security'. Although the conversations among the Eurosceptic and pro-EU actors regarding Turkey's definition of 'national security' have remained somewhat muted, a beginning has nevertheless been made. The point being that unless unacknowledged assumptions regarding Turkey's national security needs and interests are questioned by the pro-EU actors, the discourse of the Eurosceptics is likely to prevail and continue to seek to marginalise the calls for change given the 'metaphysical punch' (Der Derian 1995: 24-25) commanded by the word 'security'.

The article falls into three sections. The following section discusses the relationship between security and globalisation, and gives examples from the Turkish case. The second section looks at the 'traditional' discourse on security that has prevailed during the Republican era. The third section seeks to identify changes in the 1990s in Turkey's security discourses by focusing on the debates on the EU. The article concludes by considering the likelihood of further changes in Turkey's security discourses. 


\section{The relationship between security and globalisation}

In the 1990s, as the literature on globalisation rapidly grew, the relationship between globalisation and security received scant attention (Clark 1999: 107-126; Cha 2000; Coker 2002). This was partly to do with the optimism of the so-called 'hyper-globalisers' who expected the world to become a more 'secure' place as a side effect of further globalisation as states resolve their conflicts peacefully through sharing common ways of thinking (Barber 1995; Friedman 1999) and through realising that a breakdown in business relations would be too costly (Ohmae 1994: 13-14). Critics of this view pointed to the destructive impact of the global integration of production and finance on the peripheries of the world and argued that the hyper-globalisers failed fully to see the processes of 'structural violence' perpetuated by the global forces (Hurrell \& Woods 1995; Thomas 1997). Notwithstanding their differences, both approaches to the relationship between globalisation and security share what Clark (1999) has referred to as an 'externalist' outlook in that they treat globalisation as an 'out there' phenomenon. Clark maintains that globalisation is an 'in here' occurrence; the changes that are taking place are integral to the state. The process of globalisation does not merely transform the security environment within which states operate; it also transforms the state (also see Guéhenno 1998-1999: 7).

In a non-globalised world, 'political communities both guaranteed their members' security and posed the main threat to the security of other communities' (Guéhenno 1998-1999: 9). This changed with the impact of globalisation: 'the threat is no longer another community, but rather the internal weakening of communities' (Guéhenno 1998-1999: 10). The problem is not only that the state's grip over political processes is weakening, but also that politics is being displaced as an increasing number of issues are placed 'beyond the borders of the state and hence state-sponsored political processes' (Leander 2001: 13-14). Issues such as global warming, gendered violence and human cloning cross boundaries and place themselves on the agendas of states. Accordingly, 'previously de-politicised areas of decision-making now find themselves politicised.... They are opened to public doubt and debate mostly in the face of resistance from the powerful institutions that monopolise such decisions' (Beck 2000: 99). The 'security reflex' of some has been that of trying to resist the politicisation of issues that are 'sensitive' (by their own definition).

In Turkey, this has been observed in the past twenty years in that with the liberalisation of the economy, Turkey's business elite has begun to more actively influence political processes. Civil societal actors in general have benefited from this environment and begun to get their voices heard with the help 
of transnational coalitions (which they themselves help to build). Women's organisations, for instance, have been influenced by feminist theorising and practices as with the Convention on the Elimination of All Types of Discrimination against Women (CEDAW). Arat (2001: 29) maintains that 'it was with reference to CEDAW and the four United Nations world conferences on women that women in Turkey most concretely pursued their rights both through civil society and the state'. Eventually, the Turkish government modified its position on women's issues. Arguably, this is a prime example of how non-governmental actors, empowered by the global context (in this case, a context within which women's rights as human rights gained prominence) and with the help of transnational coalitions, could influence political processes at home.

Globalisation's empowerment of non-state actors has had implications for the methods used by states to guarantee the security of their citizens. Indeed, the state's monopoly on the use of legitimate violence is contested by internal and external actors alike. The challenges of non-state actors take the form of armed movements that rise against the government or private military companies that offer their services to the warring parties (including the government). Growing media presence (another dimension of globalisation) has meant that governments use violence under the media spotlight and justify their actions to audiences both at home and abroad. Turkey's struggle with the PKK was conducted under this media spotlight. Turkey's politicians and civilian-military bureaucratic elite resented this, as they did, for example, when the German government suspended the delivery of weapons to Turkey to investigate whether they were used in the struggle with the PKK in April 1994.

Globalisation not only empowers the 'new' actors, but also creates multilateralist pressures to cooperate with sub-state and trans-state parties rather than traditional allies (Cha 2000). Although some traditional actors have voiced their resentment regarding such pressures and chose to use 'securityspeak' when discussing issues such as cultural pluralism or linguistic rights that are addressed by these new actors (see below), other actors within Turkish bureaucracy began to relax their attitude towards an otherwise sensitive issue: that of refugees and asylum policy. Indeed, in the second half of the 1990s (especially since 1999) segments of the Turkish bureaucracy have begun to cooperate more effectively with non-governmental actors as well as the United Nations High Commission for Refugees (UNHCR) (Kiriş̧̧i 2001, 2002). Arguably, this change in policy constitutes an instance of a transformation taking place in Turkey. As Kirişçi (2002: 26) has maintained, 'the new policy is not only indicative of the degree of leverage that the EU can enjoy in its relations with a candidate country but also the change taking place within Turkey'. 
Understood as such, globalisation of security is different from 'internationalisation' of security. As Clark (1999: 109) has argued,

globalisation requires a change in the nature of the security state itself, not simply the setting in which it finds itself... This is not a necessary condition of multilateralism or internationalism. States can opt into, or out of, collective defence and collective security arrangements without experiencing fundamental change to themselves. In sharp contrast, it is this focus on the simultaneous transformation of the state and its environment that sets globalisation apart from those other threats.

The trend towards internationalisation of security (understood as increasing recourse to collective security and multilateral efforts) has been recognised in the field of strategy for a long time (see Guéhenno 1998-1999; Held \& McGrew 1993: 266). Throughout history, states have attempted to address issues raised by 'strategic globality' (Rasmussen 2002: 325-327) through forming alliances, security regimes, collective security organisations and security communities. The ending of the Cold War is considered to have further encouraged the internationalisation of security affairs (Held \& McGrew 1993: 267). Globalisation of security is different from internationalisation of security in that the former involves the latter, but goes beyond being an inter-state phenomenon.

It was as part of the process of joining the EU that the challenges of globalised security were strongly felt in Turkey. Although the process of joining the North Atlantic Treaty Organisation (NATO) did make an impact on political processes in Turkey, the changes incurred were rather minimal. This had partly to do with the Cold War context in that minimal interference in the internal affairs of allies became the norm for reasons of maintaining bloc solidarity in the face of the Soviet threat. This, however, should not be taken to suggest that Turkey's membership of NATO had no impact on its political processes. According to Jenkins (2001: 35), joining NATO and, in particular, Turkey's participation in the Korean War boosted the military's self-esteem and brought it back to the forefront of Turkish politics following the 1923-1950 period when 'the military as an institution remained impoverished and politically quiescent' notwithstanding the prominence of former soldiers in politics. What should also be noted is that following the transition to multiparty politics (1946) and, in particular, the aftermath of the 1950 elections that brought the Democrat Party to power, there was a change of blood within the ruling elite in that former soldiers' role in the shaping of political processes declined. Then, what seems to have enabled the military to get more actively involved in Turkish politics was not only NATO membership and the military's 
increased confidence, but also changes in the domestic scene. What is more, whatever changes incurred as a result of NATO membership were understood and responded to within an inter-state framework. Indeed, notwithstanding the 'international outlook' military officers gained when serving abroad, their approaches to world politics in general, and NATO in particular, remained 'dominated by a purely national and regional outlook' (Karaosmanoğlu 2000: 209; see also Erkaya \& Baytok 2001: 27).

One further analytical distinction remains to be made: that between globalisation and the expansion and intensification of international society. During the nineteenth century, the expansion and intensification of international society made a significant impact on the foreign and domestic policies of the Ottoman Empire. Although the norms of international society were viewed as threatening the internal cohesion and strength of the state, they were nevertheless adopted by Ottoman statesmen. According to Karaosmanoğlu (2000: 207), '[Ottoman statesmen] used the policy of reform in two different ways. At times, they exploited it in order to attract foreign support. ... Sometimes, however, in demonstrating commitment to modernization, Turks hoped to avert European interference.'

The transformative effect of globalisation is different from that of the expansion and intensification of international society. After all, international society is a society of states. In many ways, it is supportive of state security (Buzan 1995: 193). Yet, international society also threatens states by way of limiting their freedom of action, subordinating them to larger bodies and eroding their distinctive identity. The crucial difference between the two is that international society rests on the 'inside/outside' divide (Walker 1993), whereas globalisation blurs it (Guéhenno 1998-1999: 6; Clark 1999: 111).

Mary Kaldor (1999) has made this point succinctly with reference to the changing character of war and the need for new conceptualisations - that is, 'new war'. She has argued that the wars of the 1990s have served to break down the binary distinctions on which the conventional approach to security was built. Kaldor defines these 'new wars' as 'wars that have political goals but in practice are a kind of mixture between wars (organized violence for political goals), massive violations of human rights (organized violence against individuals), and organized crime (private organized violence)'.

In these wars, the binary distinctions that were so important for the state system and the bloc system have begun to break down - between internal and external, public and private, rule of law and anarchy.... These wars spill over borders, through refugees and asylum seekers, through organized crime, and through identity-based networks. Nor does the state maintain control over organized violence. (Kaldor 2000: 58) 
Understood as such, Kaldor's definition of 'new war' captures the impact made by globalised security (see also Guéhenno 1998-1999: 10).

Kaldor's recommended approach to cope with the challenge of globalised security is also of significance for the argument here. She maintains that 'any effective approach to security has to be aimed at the extension of the rule of law and civil society across borders. If it is no longer possible to insulate civil society territorially, then it can only be preserved through territorial extension' (Kaldor 2000: 58). Building upon this argument, Kaldor has suggested that this could be done through further enlargement of the EU so that its definition and practices of security would be exported to other states. Accordingly, Kaldor considers the 1999 decision of the EU to give Turkey candidate country status as a positive step in the direction of expanding civil society across borders (Kaldor 2000: 60). Yet, what Kaldor fails to note is that those at the receiving end could consider the territorial expansion of civil society beyond the EU's boundaries as a threat to their national security. Indeed, as will be discussed below, the EU's call for reforms have been presented as a source of insecurity by Turkey's Eurosceptics.

This should not be taken to disregard the merits of the expansion of civil society beyond the boundaries of the EU. Rather, the point here is that 'the problem of security and the state is ... not a single one' (Buzan 1995: 203-204), and that although all states are faced with the challenge of globalisation, they give different responses. Buzan maintains that those states that try to be open in relation to the international system are more likely to choose narrow security agendas because most types of interaction are not seen as threatening. These states are expected to resist attacks, but they also try to make themselves militarily transparent and non-threatening to others. On the other hand, closed states see 'most types of interaction as threatening' (Buzan 1995: 203-204). They are expected to respond to the politicisation of previously de-politicised (so-called 'sensitive') issues by securitising them (following Waever's (1995) definition of the term). The responses of Turkey's Eurosceptics suggest that they would like to opt for closure in the attempt to resist the transformation brought about by the process of globalisation. In doing this, they have thus far upheld what is referred to here as the 'traditional discourse' on security and used it to frame the debates on Turkey's membership of the EU.

\section{Traditional discourse in the Republican era}

There is no obvious answer to the question: What really makes something a security problem? Traditionally, the attraction of national security for policy- 
makers has been rooted in its ambiguity since it has been used to justify anything and everything. As Bock and Berkowitz (1966: 132) noted, during the early years of the Cold War, there was 'hardly a national policy that [had] not been publicly justified by an almost ritualistic appeal to some mystical "national security interest"'. As Wolfers (1962: 147) suggests political formulas such as national security, 'while appearing to offer guidance and basis for a broad consensus ... may be permitting everyone to label whatever policy he favours with an attractive and possibly deceptive name'. If, for example, funds are going to be allocated to protect business interests abroad, representing the issue as a national security concern makes it more acceptable to the public who might otherwise have been more sceptical had the issue been presented simply as one of protecting business interests. This, in turn, is rooted in what Der Derian (1995: 24-25) has termed the 'metaphysical punch' of security in that labelling an issue as a security issue renders it of particular urgency and justifies the mobilisation of extraordinary measures to address it.

While Wolfers warned against policy-makers' use of the label 'national security' to further their policy goals, Waever has embraced this process as the only way security is. Making use of language theory, Waever (1995: 55) has presented an understanding of security as a 'speech act':

In this usage, security is not of interest as a sign that refers to something more real; the utterance itself is the act. By saying it, something is done (as in betting, giving a promise, naming a ship). By uttering 'security', a state-representative moves a particular development into a specific area, and thereby claims a special right to use whatever means are necessary to block it. (emphasis in original)

Understood as such, the agency of state representatives is crucial in the process of securitisation in that 'by definition, something is a security problem when the elites declare it to be so'. After all, 'in naming a certain development a security problem, the "state" can claim a special right, one that will, in the final instance, always be defined by the state and its elites' (Waever 1995: 54; emphasis in original).

The traditional discourse on security in Turkey has been that of the civilian-military bureaucratic elite since the foundation of the republic. Indeed, there has been little (if any) public questioning of Turkey's definition of 'national security' during this period. ${ }^{1}$ The traditional discourse has had two major components - namely, a 'fear of abandonment and fear of loss of territory' (Criss \& Karaosmanoğlu (n.d.): 12) and an assumption of 'geographical determinism'. To start with the first component, although the 'fear of abandonment and fear of loss of territory' is often associated with the Sevrés Treaty 
(1920), its origins arguably lie deep in Ottoman history. As noted above, the expansion and intensification of international society during the nineteenth century, when coupled with the decline of the Ottoman Empire, meant that the Ottoman state had to adopt norms that were considered threatening to the security and integrity of the empire. The ensuing rise of nationalism among Christian peoples and later Muslim Arabs (which was enabled by the adoption of these norms), and the demands made in the aftermath of the First World War on Ottoman territories in line with the principle of national selfdetermination, left a negative imprint on the psyche of many in Turkey.

This 'fear of abandonment and fear of less of territory' manifested itself as minimal participation in international affairs during the early years of the Republic. Indeed, well until the end of the Second World War,Turkey's foreign policy bordered on isolationism, notwithstanding a number of treaties. Perhaps unsurprisingly, both the Sadabad Pact (1937) and the Balkan Pact (1934) were designed to maintain the status quo in the regions surrounding Turkey (Akşin 1991: 198-201, 263-268). During this period, relations with the West were also kept to a minimum, while keeping on track the project of Westernisation. In the aftermath of the Second World War, joining NATO meant not only the entrenchment of Turkey's identification with the West, but also helped to allay the 'fear of abandonment' and keep at bay the 'fear of loss of territory' by providing both security and recognition. Still, Turkey's policymakers opted for caution more often than risk during the Cold War era (see Sezer 1981; Karaosmanoğlu 1988a; Sayarı 2000; Mufti 1998).

The end of the Cold War has not only meant the 'emergence of issues from the grip of the Cold War' (as with identity, human rights, democratisation) (Clark 1999: 112), but also removed the reasons for uncritical acceptance of allies with all their shortcomings for reasons of maintaining bloc solidarity. Accordingly, Turkey's policy-makers have had to face the forces of globalised security that were no longer 'mitigated by a potent counter-weight such as the Cold War's strategic threat' (Guéhenno 1998-1999: 8). It was during the postCold War period that coincided with Turkey's struggle with the PKK and application to join the EU that the sub-text of 'fear of abandonment and fear of loss of territory' was turned into text in Turkey's security discourses.

Consider, for example, the following excerpt from General Nahit Şenogglu's (then Commander of the Military Academy) address to students made at the beginning of the academic year:

You will see that Turkey has the most internal and external enemies of any country in the world. You will learn about the dirty aspirations of those who hide behind values such as democracy and human rights and who want to take revenge on the republic of Atatürk. (Jenkins 2001: 90) 
General (Ret.) Dogan Bayazit (former Secretary General of the National Security Council, 1992-1995) re-stated this fear in discussing the Kurdish issue:

For centuries, external forces, which find a self-sufficient and powerful Turkey, in this region with enormous geopolitical advantages, as threatening to their interests have adopted the covert policy of the "creation of a Kurdish state' within Turkey. Indications are such that this policy is currently being forced upon the future of the country. Whenever this country has an opportunity to prosper, an ethnic or religious problem makes its appearance. (Bayazit 1998: 82-83)

The 'fear of less of territory' turns into text even more forcefully in General (Ret.) Suat İlhan's book on Turkey and the EU (aptly titled Why 'No' to the European Union). Illhan's argument is that the EU's demands for reform constitute, on the part of the West, an attempt to achieve what was not possible in the aftermath of the First World War - namely, the dividing up of Turkey. He writes:

The EU achieves the following as a result of Turkey's candidacy for membership: it enhances its horizons and sphere of influence to include Caucasia, Middle East, Central Asia; attains the opportunity to enhance and reinforce the advantages created by the Customs Union treaty... prepares the ground for the resolution of the Turco-Greek dispute in favour of Greece ... paves the way for carving out Turkish territories via endeavours in 'minority rights'; and generates hope for the resolution of the 'Eastern Question' by way of side-tracking Turkey. (Ilhan 2000:22)

As seen in Şenoğlu, Bayazıt and İlhan's words (also see Manisalı 2001: 128), 'the fear of abandonment and fear of loss of territory' remains a major component of the traditional discourse in the post-Cold War era.

The second major component of the traditional discourse on security has been the assumption of geographical determinism (see, e.g., Sander 1984). Indeed, Turkey's geographical location has been utilised to point to its unique security needs and interests. 'If Turkey is famous for something, that is its tough neighbourhood,' quipped General (Ret.) Ergüvenç (1998: 32). Consider, for instance, the following excerpt from the White Paper (Beyaz Kitap) published by Turkey's Ministry of National Defence (2000) that locates Turkey in an influential location in

- The Middle East and the Caspian Basin, which have the most important oil reserves in the world, 
- The Mediterranean Basin, which is at the intersection of important sea lines of communication,

- The Black Sea Basin and the Turkish Straits, which have always maintained their importance in history,

- The Balkans, which have undergone structural changes as the result of the break up of the Union of Soviet Socialist Republics (USSR) and Yugoslavia, and

- The center of the geography composed of Caucasia, which has abundant natural resources as well as ethnic conflicts, and Central Asia.

In the preface to the White Paper, Sabahattin Çakmakoglu (then Minister of National Defence) explains the significance of this geographical position by noting that 'Turkey is located in the center of a region full of instabilities and uncertainties, such as the Middle East, Caucasus and the Balkans, where the balances are in a process of change'. Indeed, many of the developments that have characterised the post-Cold War era (such as the dissolution of the Soviet Union, the formation of new [ex-Soviet] republics, the break-up of Yugoslavia, the war in Bosnia, the Iraqi invasion of Kuwait and the Gulf War that ensued, the United States-led war on Iraq and the now defunct Middle East peace process) took place in Turkey's neighbourhood. In this sense, the 1990s seem to have only substantiated the prevalent conviction that Turkey's geopolitical location determines its foreign and security policy choices. In Çakmakoğlu's (2000) words, the 'unstable situation in the Balkans, Caucasus, Central Asia and the Middle East, our neighbors' policy toward Turkey and our 8,300 kilometers long costs [sic] entail us to develop our national security policy in this way'.

The assumption of geographical determinism shapes not only Turkey's security policies, but also its political processes in general. For example, in response to calls for democratisation, Bülent Ecevit (then Prime Minister) maintained that 'Turkey's special geographical conditions require a special type of democracy' (quoted in Aydınlı \& Waxman 2001: 385). Similarly, a member of the military bureaucracy is quoted as having said that Turkey's geopolitics 'does not allow for more democracy' (Belge 2003: 229). In reviewing the constitutional and administrative reform packages prepared in line with the wishes of the EU, some military officials were quoted as saying that Turkey is faced by threats not like any other European country and that the Copenhagen criteria should be implemented 'taking into consideration the interests and realities of the country' (Jenkins 2001: 82). Arguably, such statements exemplify the ways in which certain representations of Turkey's geopolitical location have been used to legitimise the adoption of a 
particular conception of national security that does not allow for further democratisation.

The assumption of geographical determinism, which such statements are built upon, glosses over the essentially political character of conceptualising security, formulating security policies and practising security. In other words, this approach takes the 'political' out of geopolitics. Conceptualising security, however, is a political process. Treating geographical features as determinants of security policy is a political act in itself (see Agnew 1998; Agnew \& Corbridge 1995; Dalby 1991; Ó Tuathail 1996). Indeed, Turkey's policy-makers have made references to the same geographical location to justify both caution ('Turkey's unique sensitivities' argument) and risk ('Turkey's unique opportunities' argument) in the formulation of policies depending on their policy preferences. This, in turn, is symptomatic of the unacknowledged and unquestioned assumption that geography overrides political processes in shaping not only security policies, but politics in general.

To recap, in addition to a feeling of 'fear of abandonment and fear of loss territory', an assumption of geographical determinism has characterised the traditional security discourse that has prevailed during the Republican era. This is not to suggest that what is referred to here as the 'traditional discourse' went totally unchallenged. Multiple discourses on security contest with each other within states. Yet, it is the discourses of the state elite that get to shape practices, while others seek to influence policy-making. Security discourses, in Lipschutz's (1995: 8) words, 'are neither strictly objective assessments nor analytical constructs of threat, but rather the products of historical structures and processes, of struggles for power within the states, of conflicts between the societal groups that inhabit states and the interests that besiege them'. The traditional discourse on security in Turkey is a legacy of the Ottoman past (Lowry 2000; Çandar 2000). It was this discourse that has shaped security policies since 1923, during which time Turkey was transformed from a warridden young Republic into a functioning democracy (albeit with its shortcomings). As circumstances changed with the globalisation of security, pressures evolved for the security discourse to change as well. What follows is an analysis of the extent to which Turkey's security discourses have changed in the last decade.

\section{Debates surrounding EU membership}

During the 1990s, the National Security Policy Document (the so-called 'Red Book') was modified twice to put a broader range of issues on Turkey's 
security agenda. In April 1997, regressive Islamism (irtica) and Kurdish separatism were identified as major threats to Turkey's security. This modification was a follow-up to the changes made in 1992 when internal threats (separatism and terrorism) were prioritised in Turkey's security conceptualisation (Özcan 1998). The 1997 amendment further reinforced the trend established in 1992 to prioritise internal threats; the Office of the Chief of Staff, who publicised this amendment to the National Security Policy Document, also declared that 'internal threats against the territorial integrity of the country and the founding principles of the republic became more grave than external threats'. The broadening of Turkey's security agenda was not without its critics whose views were encapsulated in Özcan's (1998: 90) remark that by the end of the 1990s, it had become 'difficult to find a political and societal topic that does not concern national security'.

It is important to note here that these changes in the National Security Document were made in the post-Cold War setting where the challenges of globalised security were strongly felt. In the case of Turkey's struggle with the PKK, for instance, the state had to operate in an environment in which its monopoly of legitimate violence was contested both internally (in the form of an armed movement conducting terrorist acts of violence) and externally (as with the calls for a political, and not merely military, solution to the problem). Second, liberalisation of the Turkish economy during the 1980s and 1990s meant that the activities and relations of non-state actors were less and less amenable to state control and were conducted through transnational networks over which the state had little influence. Third, the revolution in information technology and growing media presence meant that the struggle with the PKK had to be conducted 'not only in traditional political settings, but increasingly through an international media which escapes the control of the state' (Leander 2001: 25). Given the global environment that enabled the voices of non-state actors to be heard when framed within the context of rising concerns, it became much more difficult for the state to get across its own representation of events.

Coupled with the difficulties the state had to face due to the challenge to its monopoly on legitimate use of violence were changes in the economic and societal sectors that enabled the 'new' actors to join forces with like-minded international and/or transnational actors. Among these were the Islamist actors whose activism was enabled by the liberalisation of the Turkish economy as well as encounters with EU actors. Toward the end of the 1990s, the Turkish government targeted Islamist Hezbollah terror together with that of the PKK, thereby putting into practice the broadened security agenda.

Thus, the broadening of Turkey's security agenda took place in an environment beset by the challenges posed by globalised security. Although the 
broadening of the security agenda was not without its critics (Cizre 2000, 2003, 2004; Özcan 1998, 2002), it was in the aftermath of the 1999 decision of the EU (which accelerated the reform process in Turkey) that a public debate on Turkey's definition of 'national security' began to emerge. This debate took place between the Eurosceptic and pro-EU actors and focused on the security implications of some of the reforms demanded by the EU. Although both sides to the debate have continued to profess support for Turkey's EU membership, their discourses began to diverge on issues to do with national security. While neither of the two groups openly oppose Turkey joining the EU, the Eurosceptics formulate their arguments in 'yes, but...' format and use 'security-speak' when voicing their concerns. See, for example, the following words of Professor Erol Manisalı (2002: 64-65):

if it [the EU] is going to take over the market, diminish the national industry, govern the bureaucracy from Brussels, make demands contrary to my national interest on Cyprus, the European Army, PKK and Armenian issues, and refuse to admit Turkey unless these demands are met, I would say 'Yes, it is in my favour if the EU lets me in' but add that 'it is trying to divide up Turkey and make me dependent and is putting forward these conditions so as not to admit Turkey'. (emphasis added)

General İlhan Kılınç (secretary General of the National Security Council) formulates his views in the same format:

I am in favour of joining the EU. But I have no hope for us entering the EU. They will not open this door to us.... The EU has never been on Turkey's side.... [It] has supported terrorist organizations in Turkey openly as well as clandestinely. (emphasis added)

Arguably, Manisalı and Kılınç's words point to the ways in which Turkey's traditional security discourse is used to resist the transformation that is part and parcel of globalisation. Manisalı and Kılınç's remarks were received critically by pro-EU actors in the Turkish media (see, e.g., Belge 2003: 303-305; Yetkin 2002: 262-269).

The Eurosceptics are aware of the potential benefits of joining the EU. Yet, they consider the reforms demanded by the EU as threatening Turkey's national security. Thus, when EU actors call for changes in Turkey's policies, these are interpreted within an inter-state framework and represented at best as 'interference in Turkey's domestic affairs' and at worst as 'attempts to carve out portions of Turkey's territory'. Although the Eurosceptics are aware of the not-so-bright prospects that await Turkey if it fails to join the EU, their worstcase scenario is rather different. They are worried that Turkey would make all 
the reforms demanded by the EU (including reforms in the make-up and duties of the National Security Council) and the EU would still deny (full) membership to Turkey (Illhan 2000, 2002; Manisalı 2001, 2002). In his speech quoted above, Manisalı identified the problems likely to be caused by the adoption of EU norms, including an erosion of the Turkish state's monopoly on the legitimate use of violence, and maintained that if Turkey carries on making the reforms demanded by the EU, 'in 15 years' time, not even the Turkish Armed Forces would be able to lift a finger'. The implication being that the Turkish military's ability to cope with internal and external threats to security would be curbed.

What is interesting to note here is that while upholding the traditional discourse on security (by invoking the 'fear of abandonment and fear of loss of territory' and making references to Turkey's geographical location as a determinant of its security policy), the Eurosceptics have, at the same time, presented their position as not merely a response to Turkey's unique and unchanging characteristics (as with its geographical location and domestic make-up), but as responses to a world conceived in terms of globalisation. İsmail Hakkı Karadayı (then Chief of Staff) in a speech entitled 'Factors that Cause Change and Their Impact upon Conceptualisations of Security' delivered at a seminar organised by the Organization for Security and Cooperation in Europe (OSCE) in January 1998, identified two categories of threats that should be put on the security agenda:

The first category includes illegal trafficking of arms and drugs, international terrorism and condoning of terrorism in cases where it is considered as war of independence, the proliferation of weapons of mass destruction and environmental damage. The second category includes ethnic conflicts, intolerance, radical nationalisms and all kinds of separatism, and human trade in the form of migration.

Karaday1 maintained that these new risks and threats were more dangerous because there was no longer a single identifiable enemy. Rather, the new security environment was characterised by a range of threats posed by a multiplicity of actors at different levels. However, although the broadened security agenda sought to be justified within the context of globalised security, practices were increasingly designed to resist the transformation inside (as with the emergence of 'new' actors, displacement of politics and the erosion of the state's monopoly on the legitimate use of violence) that is a part and parcel of the process of globalisation. Hence the emphasis put on national security remaining within existing inter-state frameworks (albeit with a dash of multilateralism). 
The pro-EU actors have long presented their position as responses to a globalising world, but stressed the economic and political dimensions to the neglect of security (see Ugur 2003). Two separate yet interrelated developments have begun to change this tendency. The first was Mesut Yilmaz's (then deputy Prime Minister and Minister responsible for Turkey-EU relations) public challenge to the Euosceptics on their own ground - that of national security. Arguably, his move prepared the ground for others' articulations on Turkey's definition of 'national security' (see below for further discussion). The second development was the emergence of a group of pro-EU actors who sought to use 'security speak' when discussing the issue of Turkey's membership of the EU. Needless to say, both developments were enabled by the creation of a favourable environment following the capture of PKK leader Abdullah Öcalan, the EU's decision to include Turkey in the list of candidates for accession and the economic crisis of 2000 that triggered a major re-think in certain circles - in particular, the so called 'new actors'.

Speaking at the Congress of the Motherland Party in August 2001, Yilmaz maintained that Turkey's integration into the EU is delayed by the "national security syndrome' that thwarted changes in Turkey's Constitution and other reforms demanded by the EU. According to Yllmaz, the problem was not only that Turkey's conceptualisation of 'national security' was far too broad compared to its EU counterparts, it was also that in Turkey 'national security' was defined behind closed doors. The public and their representatives had little or no say on these definitions, which restricted their freedom of action. In a speech he delivered at a meeting of the Motherland Party's Chairmanship Council (that took place ten days after the Party Congress where he made the aforementioned speech), Mesut Yllmaz maintained that: '[National security] is an issue that concerns everyone in Turkey, therefore it should be discussed not only by the political parties, but by the public as well' (BBC Monitoring International Reports, 15 August 2001. Available online at: http//wwwb. business.reuters.com (accessed 25 July 2002)).

Yllmaz's words provoked a mixed reaction in the Turkish media. While some were receptive to his critique, others criticised his choice of topic and/or venue. The Turkish General Staff gave a strong reaction maintaining that it was more appropriate to discuss issues, which is about the prosperity and happiness of people, on platforms which are not tainted with political interests' ('Turkish General Staff Issues Statement on "National Security Concept"', $B B C$ Monitoring International Reports. Available online at: http://wwwb. business.reuters.com (accessed 25 July 2002)). The General Staff's statement made use of the traditional discourse by invoking both the assumption of geographical determinism ('Turkey [is] compelled to live in a geography stretching from Cyprus, Caucasus, the Middle East and northern Iraq where balances 
could not be fully established') and 'fear of isolation and fear of loss of territory' ('the Turkish republic has for years have been under constant threat aimed at its secular, democratic and unitary republic and for over 15 years a separatist terrorist campaign staged ruthless massacres with the support of some of the neighbours of Turkey').

The reactions of Yilmaz's governmental colleagues (such as National Defense Minister Sabahattin Çakmakoğlu and Devlet Bahçeli, the Deputy Prime Minister and Head of Nationalist Action Party) suggested that they too were not comfortable with the idea of opening up Turkey's definition of 'national security' for public debate. Çakmakoğlu (2000), when asked whether there was a problem in the process through which Turkey's definition of 'national security' is formulated, said: 'According to my point of view, there is not any problem. National security policy does not consist of personal assessments. It is developed by taking into consideration Turkey's strategic position and its neighbours.' Then, the Turkish General Staff and Minister of Defence both believed that although national security may indeed be an 'issue that concerns everyone in Turkey', it need not be discussed in public (see Cizre 2003 for further discussion).

Y1lmaz's words found a receptive ear in some non-governmental actors along with the media. The Turkish Industrialists' and Businessmen's Association (TUSIAD) issued a press release on 8 August 2001 praising Yilmaz's move, which it considered as in 'harmony with democratic practices' (although not timely given the economic situation in the country). The Organization of Human Rights and Solidarity for Oppressed People (MAZLUMDER) also supported Yilmaz. However, not all non-governmental actors agreed. Chairman of the Ankara Chamber of Trade (ATO) Sinan Aygün and the Board of Directors of the Federation of Turkish Labour Unions (Türk-İss - a longstanding Eurosceptic voice in Turkish politics) both issued statements in support of the General Staff's stance. The arguments of Yilmaz's critics rested on two pillars. The first was the assumption that Turkey's national security conception is pre-determined by its geographical location and domestic make-up, and that such givens do not leave much room for discussion. The second pillar was the consensus that national security is far too important and delicate an issue to be discussed outside National Security Council meetings.

Although this debate (which was not a real debate, according to Belge (2003: 269), but one as to whether to have a debate) remained limited to the media, representatives of political parties and some civil societal actors, it was nevertheless instrumental in clarifying the positions of those who had until then professed to be in favour of joining the EU. Indeed, it showed how the differences on issues to do with national security cross cut the Eurosceptic/proEU divide. Not all actors who would otherwise define themselves as staunchly 
pro-EU sided with Yılmaz (as with the head of True Path Party, Tansu Çiller, who led the way when signing the Customs Union Treaty with the EU). Although their position could perhaps be explained away with reference to political expediency, the point here is that such resistance to even considering opening up Turkey's definition of 'national security' for debate is rooted in unacknowledged assumptions regarding what Turkey's national security needs and interests are - assumptions that the actors give away by resorting to the traditional discourse on security.

At around the same time as Yllmaz's call for opening up national security to debate, a second development took place with the emergence of a group of pro-EU elite who began to use 'security-speak' when making the case for EU membership. While some remained content with uttering the line the 'EU will be good for Turkey's security as well' (see, e.g., Kaleağası 2003), others began to develop an alternative discourse. General (Ret.) Ergüvenç articulated the pro-EU position in an article entitled 'New Priorities for National Security' (Ergüvenç 1999, 2000a, 2000b). Criticising Turkey's security strategy for its over-reliance on military defence, Ergüvenç (1999: 46) maintained that national security in the twenty-first century should be defined as 'sustaining freedom and development in a ruthlessly competitive environment'. This, in turn, could not be done by relying on the military instrument alone; it has to be achieved by producing the educated human power and civilian infrastructure to compete in the global arena. The problem, according to Ergüvenç, was that further investment in the military sector diverted valuable resources away from education and research. Furthermore, Turkey no longer had the option of resolving the conflicts with its neighbours through resorting to military force given the global context that no longer condones such actions. In conclusion, noted Ergüvenç (1999: 48-49), further investment in the military sector could potentially prevent Turkey from achieving national security.

Ergüvenç was by no means unaware of the difficult situation Turkey faced as a country that borders on two different worlds: stability on the West (the EU) and instability in the south (the Middle East), which he referred to as 'Turkey's double asymmetry'. Yet, rather than resorting to the traditional discourse on security, he chose to frame the problem within the context of globalisation. Turkey's challenge, according to him, was that although recent developments have meant that the military instrument has lost its primacy in Turkey's security policy-making, traditional strategic arguments have not yet lost their relevance. Presented as such, 'Turkey's double asymmetry' is a sign of the times as presented by Guéhenno (1998-1999: 15):

This period combines classical balance-of-power calculations with elements of a different world, in which security is built on a balance of 
dependence and in which the boundaries between communities are blurred and power diluted. The methods used to ensure security in one context are precisely those that undermine it in another.

Ambassador (Ret.) Ilter Türkmen is another pro-EU actor who has expressed the need for a fresh approach to Turkey's foreign and security relations. Criticising recent changes in Turkey's security strategy Türkmen (2001: 61) wrote:

There is value in taking a critical look at our strategic culture. In recent years, Turkey has developed certain strategic mission concepts that go beyond its economic and political reach. This has been done in a context shaped by the tendency to see the region and the world as an arena of incessant conflict. Although there exists many conflicts and instability in the region surrounding Turkey, not all of these constitute a direct threat to Turkey's security.

Türkmen's (2001: 61) broader point was that the defence budget would eventually have to undergo a cutback in that it is not economically feasible to sustain the current level of defence expenditure'. This being the case, Turkey would stand to benefit from EU membership not only economically and politically, but also security-wise. Joining the EU, he argued, would eventually transform Turkey's strategic culture (also see Karaosmanoğlu 2000) and enhance its security by helping solve the Turco-Greek and Cyprus conflicts. This, in turn, would help to stabilise the broader Aegean and Mediterranean regions and help further cut back the defence budget.

To summarise, since the 1999 EU decision, differences within the group of actors who present themselves as favourable to EU membership have crystallised. While the Eurosceptics increasingly emphasised the implications the passing and implementation of EU-required reforms are likely to have on Turkey's national security, the pro-EU actors began to directly address security issues in the attempt to strengthen the case for EU membership. A fullyfledged debate has yet to emerge on Turkey's definition of 'national security' among different societal actors (as with the one on the economy). Yet, a beginning has nevertheless been made. Considering the lack of public questioning of Turkey's definition of 'national security' during the Republican period, the significance of this beginning cannot be over-emphasised.

\section{Conclusion}

What does the future hold? The pro-EU actors have made a beginning by opening up Turkey's definition of 'national security' for debate and sowing the 
seeds of an alternative discourse on security. Although it could be argued that the EU accession process would further empower the pro-EU actors who would, in turn, push for further transformation (Barkey 2000; Öniş 2003), the prevalence of the traditional discourse does not leave much room for optimism.

In the Turkish context, there is also the added complexity of the centrality of the role played by the military in shaping political processes in general and the definition of 'national security' in particular. Although some have expressed hope that the centrality of the military's role in Turkish politics is likely to change as a part of the EU membership process (Karaosmanoglu 2000: 213), others beg to differ. Jenkins (2001: 84) goes so far as to suggest that: 'Turkey's new status as an official candidate for EU membership has, if anything, prompted the military to become more deeply involved in politics as its strives to ensure that legislative changes to fulfill the Copenhagen criteria do not jeopardize its perception of national security.' Likewise, Cizre (2000: 9), in discussing the broadening of Turkey's security agenda during the 1990s, has maintained that the Turkish military has come to use the centrality of its role in defining 'national security' as a key instrument in the shaping of political processes in Turkey, and that the broadening of Turkey's security agenda is not merely an action taken in tandem with NATO, but 'reflects a particular tradition in calling for a more ambitious role for the officer corps' (Cizre 2000: 20; see also Cizre 2003: 217-218).

Space does not permit a detailed discussion as to whether the military's role in Turkish politics has increased (Cizre 1997, 2000, 2003, 2004; Jenkins 2001) or decreased (Karaosmanoğlu 2000; Heper \& Güney 1996) during the 1990s. Even if one were, for the sake of argument, to put the reservations of those who support the prior view aside, and side with those who argue that the military's involvement in politics is gradually diminishing and it is increasingly likely to only get involved in issues to do with national security, one thing remains unchanged: so long as the military is the major actor in shaping the contours of national security, its role in Turkish politics is likely to remain central. This is because, given the influence the term 'security' has on peoples' thinking and practices, those who have the power to define what 'national security' means in a given context also have the power to shape political processes. And, as Waever (1995: 54; emphasis in original) has argued, "trying to press the kind of unwanted political change on a ruling elite is similar to playing a game in which one's opponent can change the rules at any time s/he likes. Power holders can always try to use the instrument of securitisation of an issue to gain control over it.' From Waever's (1995: 55) perspective, the only alternative left open to the critics of prevalent definitions of security is that of attempting 'speech act failure' - that is, 'narrowing the field to which security 
act [is] applied' so that issues and developments could be addressed through normal politics (but see Bilgin et al. 1998: 148; see also Wyn Jones 1999). Yet, given the authority of the state elite when discussing issues to do with national security, achieving 'speech act failure' is no easy task.

Thus, the problem in the Turkish context is not only that of the centrality of the military's role in Turkish politics, but also that of the weakness of other actors who could provide alternative definitions of security and/or attempt 'speech act failure'. Indeed, in Turkey, civil societal institutions are not only relatively weak, but have not been interested in security issues for most of Republican history. Although in recent years there has been an upsurge of interest in foreign policy issues with 'lobbies drawn from communities within Turkey that trace their origins to such place as Bosnia or Azerbaijan' (Lesser 2000: 184) and a coalition of civil societal actors pushing for EU membership, a similar dynamism is not observed in issues to do with security and defence.

It is not only civil societal actors, but also their elected representatives who are not interested in security and defence issues. Every year, the defence budget goes on the nod in the Turkish Grand National Assembly. Karaosmanoglu (2000: 215) has maintained that 'the reason for this automaticity...stems more from the lack of interest of politicians than the assertiveness of the military'. Reflecting upon the power of the military members of the National Security Council, Ali Bozer (former Minister of Foreign Affairs) has argued in Yeni Şafak (31 December 2001) that this is because the civilian members do not do their homework and come unprepared, thereby paving the way for the prevalence of the military members' views.

A similar point could be made regarding the military's influence over a broad range of issues that have a security dimension (by their own definition). As Cizre (1997: 159) has maintained, 'the ability of the general chief of staff to influence the civil bureaucracy in Turkey is facilitated by the lack of career civil servants specialising in military affairs who could provide a buffer between the military and society'. Military officers themselves have occasionally complained about this lack of interest on the part of the civilian bureaucratic elite (Torumtay 1994: 57).

Thus, although the relative absence of public questioning of Turkey's definition of 'national security' could partly be explained with reference to the centrality of the military's role in Turkish politics or its command of 'securityspeak', the other part of the explanation is captured by the prevalence of unacknowledged and unquestioned assumptions regarding what Turkey's national security demands, and the lack of interest on the part of civilian (governmental and non-governmental) actors who could provide alternative definitions or attempt 'speech act failure'. Therefore, for change to occur, 'efforts designed 
to [challenge] the orthodox, security-conscious mindset in Turkey and convey what EU integration is all about' (Öniş 2003: 27) would not suffice. For Turkey's security discourse to change further (thereby shaping political processes), civil societal actors and politicians would need to develop an interest in, and knowledge of, issues to do with security. Yet, given the imprint the process of state-building leaves on civil society, it is questionable the extent to which it could constitute an escape from the traditional discourse on security (Pasha 1996). The onus is on pro-EU actors to bring an end to the nearmonopoly enjoyed by the Eurosceptics on 'security-speak' by providing dispassionate security analyses and challenging the prevalence of heretofore unacknowledged assumptions.

\section{Acknowledgments}

An earlier version of this article was presented at the 2002 APSA Convention in Boston, Massachusetts. The author would like to thank the panel participants, as well as the referees of the journal, for their valuable comments and suggestions; Ümit Cizre for invaluable comments and criticisms; and Gülden Özgediz for research assistance.

\section{Note}

1. An exception to this is the debates on Turkey's NATO membership that took place during the 1970s when Turkey-United States relations were strained because of the Cyprus issue (Firat 1997: 251-256). Even then, the debate did not question Turkey's definition of 'national security', but the methods through which security could best be maintained (see Karaosmanoglu 1988b: 305). See also Sezer (1972: 357-452) for an analysis of the debates in the media during the 1960s on Turkey's foreign policy options.

\section{References}

Agnew, J. (1998). Geopolitics: Revisioning world politics. London: Routledge.

Agnew, J. \& Corbridge, S. (1995). Mastering space: Hegemony, territory and international political economy. New York: Routledge.

Akşin, A. (1991). Atatürk'ün Dış Politika Illkeleri ve Diplomasisi [Atatürk’s foreign policy principles and diplomacy]. Ankara: Türk Tarih Kurumu.

Arat, Y. (2001). Women's rights as human rights: The Turkish case. Human Rights Review 3(1): 27-34.

Aydınl, E. \& Waxman, D. (2001). A dream become nightmare? Turkey's entry into the European Union. Current History 100(649): 381-388.

Barber, B. (1995). Jihad vs. McWorld: How globalism and tribalism are reshaping the world. New York: Ballantine Books. 
Barkey, H.J. (2000). The struggles of a 'strong' state. Journal of International Affairs 54(1): 87-105.

Bayazit, D. (1998). Kurdish Question in Turkey and the PKK terror organization. Private View (Autumn): 78-83.

Beck, U. (2000). What is globalisation? Cambridge: Polity Press/Blackwell.

Belge, M. (2003). Yaklaştıkça Uzaklaşıyor mu: Avrupa Birliği ve Türkiye [Moving further away as we get closer? The European Union and Turkey]. İstanbul: Birikim.

Bilgin, P., Booth, K. \& Wyn Jones, R. (1998). Security studies: The next stage? Naçao e Defesa (Lisbon) 84: 131-157.

Bock, P.G. \& Berkowitz, M. (1966). The emerging field of national security. World Politics 19(1): 122-136.

Buzan, B. (1995). Security, the state, the 'new world order', and beyond. In R. D. Lipschutz (ed.), On security. New York: Columbia University Press, pp. 187-211.

Çakmakoglu, S. (2000). Defence Minister says no problem with national security. BBC Monitoring International Reports. Available online at: http://wwwb.business.reuters.com (accessed 25 July 2002).

Çandar, C. (2000). Some Turkish perspectives on the United States and American policy toward Turkey. In M. Abramowitz (ed.), Turkey's transformation and American policy. New York: Century Foundation Press, pp. 117-152.

Çandar, C. (2001). Türkiye 1990-Türkiye 2010: Senaryolar [Turkey 1990-Turkey 2010: Scenarios]. Foreign Policy (Istanbul) (January-February): 56-61.

Cha, V.D. (2000). Globalisation and the study of international security. Journal of Peace Research 37(3): 391-403.

Cizre, Ü. (1997). The anatomy of Turkish military's political autonomy. Comparative Politics 29(4): 151-165.

Cizre, Ü. (2000). Politics and military in Turkey into the 21st century (EUI Working Paper). Florence: European University Institute.

Cizre, Ü. (2003). Demythologyzing the national security concept: The case of Turkey. Middle East Journal 57(2): 213-229.

Cizre, Ü. (2004). Problems of governance of civil-military relations in Turkey and the EU Enlargement Zone. European Journal of Political Research 43(1): 107-125.

Clark, I. (1999). Globalization and international relations theory. Oxford: Oxford University Press.

Coker, C. (2002). Globalisation and insecurity in the twenty-first century: NATO and the management of risk (Adelphi Paper 345). London: International Institute for Strategic Studies.

Criss, N.B. \& Karaosmanoğlu, A.L. (n.d.). Explaining Turkey's Alignment with NATO: Realism and Culturalism. Unpublished paper.

Dalby, S. (1991). Critical geopolitics: Discourse, difference and dissent. Environment and Planning D: Society and Space 9: 261-283.

Der Derian, J. (1995). The value of security: Hobbes, Marx, Nietzsche and Baudrillard. In R.D. Lipschutz (ed.), On security. New York: Colombia University Press, pp. 24-45.

Ergüvenç, Ş. (1998). Turkey's security perceptions. Perceptions 3(3): 32-42.

Ergüvenç, Ş. (1999). Milli Güvenliğin Yeni Öncelikleri [New priorities for national security]. Ulusal Strateji 2(9): 46-49.

Ergüvenç, Ş. (2000a). Türkiye-ABD-AB Üçgeninde Askeri Isşlerin Gidişatı [Trends in military affairs in the Turkey-US-EU triangle]. Ulusal Strateji 2(11): 44-48.

Ergüvenç, Ş. (2000b). MGK Üzerine [On the NSC]. Ulusal Strateji 2(14): 63-66. 
Erkaya, G. \& Baytok, T. (2001). Bir Asker Bir Diplomat: Güven Erkaya - Taner Baytok Söyleşi [One officer, one diplomat: Conversations between Güven Erkaya - Taner Baytok]. İstanbul: Do ğan Kitapçıllk.

Fırat, M.M. (1997). 1960-71 Arası Türk Dış Politikası ve Kıbrıs Sorunu [Turkish foreign policy during 1960-1971 and the Cyprus Problem]. Ankara: Siyasal Kitabevi.

Friedman, T.L. (1999). DOScapital. Foreign Policy 116: 110-116.

Guéhenno, J.-M. (1998-1999). The impact of globalisation on strategy. Survival 40(4): 519.

Held, D. \& McGrew, A. (1993). Globalisation and the liberal democratic state. Government and Opposition 28(2): 261-285.

Heper, M., \& Güney, A. (1996). The military and democracy in the Third Turkish Republic. Armed Forces and Society 22(4): 619-642.

Hurrell, A., \& Woods, N. (1995). Globalisation and inequality. Millennium: Journal of International Studies 24(3): 447-470.

Illhan, S. (2000). Avrupa Birligine Neden Hayır: Jeopolitik Yaklaşım [Why 'no' to the European Union: The geopolitical approach]. İstanbul: Ötüken.

Illhan, S. (2002). Avrupa Birligine Neden Hayır: 2 [Why 'no' to the European Union 2]. İstanbul: Ötüken.

Jenkins, G. (2001). Context and circumstance: The Turkish military and politics (Adelphi Paper 337). London: International Institute for Strategic Studies.

Kaldor, M. (1999). New and old wars: Organized violence in a global era. Cambridge: Polity Press.

Kaldor, M. (2000). Europe at the millennium. Politics 20(2): 55-62.

Kaleagası, B. (2003). Avrupa Yolunun Haritası [The map of the path to Europe]. Istanbul: Dünya.

Karaosmanoğlu,A.L. (1988a). Turkey's security policy: Continuity and change. In D.T. Stuart (ed.), Politics and security in the southern region of the Atlantic Alliance. London: Macmillan, pp. 157-180.

Karaosmanoglu, A.L. (1988b). Turkey and the southern flank: Domestic and external contexts. In J. Chipman (ed.), NATO's southern allies: Internal and external challenges. London: Routledge, pp. 287-353.

Karaosmanoglu, A.L. (2000). The evolution of the national security culture and the military in Turkey. Journal of International Affairs 54(1): 199-216.

Kasaba, R. \& Bozdoğan, S. (2000). Turkey at a crossroad. Journal of International Affairs 54(1): $1-20$.

Kirişçi, K. (2001). UNHCR and Turkey: Cooperating for improved implementation of the 1951 Convention Relating to the Status of Refugees. International Journal of Refugee Law 13(1/2): 71-97.

Kirişçi, K. (2002). Justice and home affairs issues in Turkey-EU relations. İstanbul: TESEV.

Leander, A. (2001). Globalisation and the eroding state monopoly on legitimate violence (Copenhagen Peace Research Institute Working Paper 12). Copenhagen: COPRI.

Lesser, I.O. (2000). Turkey in a changing security environment. Journal of International Affairs 54(1): 183-198.

Lipschutz, R.D. (1995). On security. In R.D. Lipschutz (ed.), On security. New York: Columbia University Press, pp. 1-23.

Lowry, H.W. (2000). Betwixt and between: Turkey's political structure on the cusp of the twenty-first century. In M. Abramowitz (ed.), Turkey's transformation and American policy. New York: Century Foundation Press, pp. 23-59. 
Manisalı, E. (2001). Yirmibirinci Yüzyılda Küresel Kıskaç: Küreselleşme, Ulus Devlet ve Türkiye [Global jam in the twenty-first century: Globalisation, nation-state and Turkey]. İstanbul: Otopsi.

Manisalı, E. (2002). Türkiye-Avrupa Ilişskilerinde 'Sessiz Darbe' ['Silent coup' in Turkey-Europe relations]. Istanbul: Derin Yayınları.

Milliken, J. (1999a). The study of discourse in international relations: A critique of research and methods. European Journal of International Relations 5(2): 225-254.

Milliken, J. (1999b). Intervention and identity: Reconstructing the West in Korea. In J. Weldes et al. (eds), Cultures of insecurity: States, communities and the production of danger. Minneapolis, MN: University of Minnesota Press, pp. 91-117.

Ministry of National Defence (2000) Beyaz Kitap [White paper] (prepared by T.C. Savunma Bakanlı̆̆ı, Genel Plan ve Prensipler Dairesi Başkanlı̆̆ı). Available online at: www.msb.gov.tr/Birimler/GnPPD/GnPPDBeyazKitap.htm\#BEYAZ KITAP (accessed 20 August 2002).

Mufti, M. (1998). Daring and caution in Turkish foreign policy. Middle East Journal 52(1): $32-50$.

Ohmae, K. (1994). The borderless world: Power and strategy in the global marketplace. London: Collins.

Ó Tuathail, G. (1996). Critical geopolitics: The politics of writing global space. Minneapolis, MN: University of Minnesota Press.

Öniş, Z. (2003). Domestic politics, international norms and challenges to the state: Turkey-EU relations in the post-Helsinki era. Turkish Studies 4(1): 9-34.

Öniş, Z \& Türem, U. (2001). Business, globalisation and democracy: A comparative analysis of Turkish business associations. Turkish Studies 2(2): 94-120.

Özcan, G. (1998). Doksanlarda Türkiye'nin Ulusal Güvenlik ve Dış Politikasında Askeri Yapının Artan Etkisi [The increasing influence of the military structure on Turkey's national security and foreign policies during the 1990s]. In G. Özcan \& Ş. Kut (eds), En Uzun Onyıl: Türk Dış Politikasında Doksanlı Yıllar [The longest decade: The nineties in Turkish foreign policy]. Istanbul: Boyut, pp. 67-100.

Özcan, G. (2002). The military and the making of foreign policy in Turkey. In B. Rubin \& K. Kirişçi (eds), Turkey in world politics: An emerging multiregional power. İstanbul: Boğaziçi University Press, pp. 18-41.

Pasha, M.K. (1996). Security as hegemony. Alternatives 21(3): 283-302.

Rasmussen, M.V. (2002). 'A parallel globalisation of terror': 9-11, security and globalisation. Cooperation and Conflict 37(3): 323-349.

Recep, A. (2002). The struggle with global terrorism and the steps that must be taken against it. Insight Turkey 4(3): 9-20.

Sander, O. (1984). Turkish foreign policy: Forces of continuity and change. In A. Evin (ed.), Modern Turkey: Continuity and change. Opladen: Leske + Burdich, pp. 115130.

Sayarı, S. (2000). Turkish foreign policy in the post-Cold War era. Journal of International Affairs 54(1): 169-183.

Sezer, D. (1972). Kamu Oyu ve Dış Politika. Ankara: Sevinç Matbaası.

Sezer, D. (1981). Turkey's security policies (Adelphi Paper 164). London: International Institute for Strategic Studies.

Thomas, C. (1997). Globalisation and the south. In C. Thomas \& P. Wilkin (eds), Globalisation and the south. London: Macmillan, pp. 1-17. 
Torumtay, N. (1994). Orgeneral Torumtay'ın Anılarl [Memoirs of General Torumtay]. Istanbul: Milliyet Yayınları.

Türkmen, İ. (2001). Güvenlik, Ekonomi ve Dış Politika [Security, economy and foreign policy]. Foreign Policy (İstanbul) (March-April): 58-65.

U gur, M. (2003). AB Hangi Koşullarda Yararlı Olabilir? [Under what conditions could the EU be beneficial?]. Görüş (January): 42-51.

Waever, O. (1995). Securitisation and desecuritisation. In R.D. Lipschutz (ed.), On security. New York: Columbia University Press, pp. 46-86.

Walker, R.B.J. (1993). Inside/outside: International relations as political theory. Cambridge: Cambridge University Press.

Wolfers, A. (1962). Discord and collaboration: Essays on international politics. Baltimore, MD: Johns Hopkins University Press.

Wyn Jones, R. (1999). Security, strategy and critical theory. Boulder, CO: Lynne Rienner.

Yetkin, M. (2002). Avrupa Birliği Bekleme Odasinda Türkiye [Turkey in the EU waiting room]. İstanbul: İmge.

Yirmibeşoğlu, S. (2003). Devleti Güçlü Kllmak [Rendering the state strong]. İstanbul: Kastaş Yayınları.

Address for correspondence: Pinar Bilgin, Department of International Relations, Bilkent University, Ankara 06800, Turkey

Tel.: +90 31229021 64; Fax: +90 31226643 26; E-mail: pbilgin@bilkent.edu.tr 